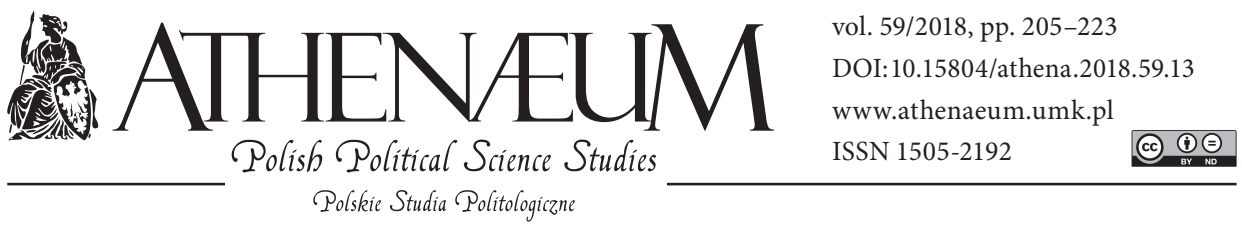

\title{
EU AGENCIFICATION? A NEW FRAMEWORK FOR THE FUNCTIONING OF DECENTRALIZED AGENCIES OF THE EUROPEAN UNION*
}

\author{
AGENCYFIKACJA UE? NOWE RAMY FUNKCJONOWANIA \\ AGENCJI ZDECENTRALIZOWANYCH UNII EUROPEJSKIEJ
}

Agnieszka Nitszke**

\begin{abstract}
EU decentralized agencies multiplied over the years in response to new challenges and developing needs of the EC/EU. The process has been intensified since the $1990^{\text {s }}$ as a result of creation of the internal market. However, this multiplication was so chaotic and uncoordinated that significant differences in the status and functioning principles of the agencies emerged. At the beginning of the 2000s, a need to create minimum standards common to all such entities became apparent. Activity initiated at that time led to the presentation by the European Commission in 2012 of the so-called Roadmap to regulate matters related to establishment, scope of activity and competences of EU decentralized agencies. In recent years, especially in English-language literature, the new term agencification is gaining popularity. This concept is used not only in the context of EU agencies, but has a wider application and refers
\end{abstract}

\begin{abstract}
Agencje zdecentralizowane były tworzone na przestrzeni lat, stanowiąc odpowiedź na nowe wyzwania i potrzeby WE/UE. Nasilenie tego procesu miało miejsce od lat 90 . i związane było $\mathrm{z}$ tworzeniem rynku wewnętrznego. Proces ten był na tyle chaotyczny i nieskoordynowany, że pojawiły się znaczące różnice $\mathrm{w}$ ich statusie i zasadach funkcjonowania. Na początku lat dwutysięcznych pojawiła się potrzeba stworzenia minimalnych standardów wspólnych dla wszystkich tego typu podmiotów. Działania rozpoczęte wówczas doprowadziły do przedstawienia przez Komisję Europejską w 2012 r. tzw. mapy drogowej, mającej uporządkować materię związaną z tworzeniem, zakresem działalności i kompetencjami UE. W ostatnich latach, szczególnie w literaturze anglojęzycznej, na popularności zyskuje nowy termin: agencification, który można przetłumaczyć na język polski jako ,agencyfikacja”. Pojęcie to nie
\end{abstract}

* The paper is financed from the European Union Erasmus programme under the Jean Monnet Chair EUCRIS grant (no 575240-EPP-1-2016-1-PL-EPPJMO-CHAIR).

** Jagiellonian University in Kraków, Institute of Political Science and International Relations. 
to a quite common phenomenon of delegation of competences and regulatory powers by state institutions to specialized units formed for just such purpose. Similarities between the national and the EU level with regard to agencification do not only concern the process of establishing the agencies, but extend also to certain general principles in autonomization of such entities.

Keywords: EU agencies, EU institutional system, agencification jest używane tylko w kontekście agencji UE, ale ma szersze zastosowanie i odnosi się do zjawiska dość powszechnego, związanego $\mathrm{z}$ delegowaniem kompetencji i uprawnień regulacyjnych przez instytucje państwowe na specjalnie w tym celu tworzone wyspecjalizowane jednostki. Podobieństwa między poziomem krajowym a unijnym w nawiązaniu do agencyfikacji nie odnoszą się tylko do procesu tworzenia agencji, ale wskazują na pewną generalną prawidłowość dotyczącą autonomizacji tego typu jednostek.

Słowa kluczowe: agencje UE, system instytucjonalny UE, agencyfikacja

\section{INTRODUCTION}

European integration is a multifaceted and multi-level process. Each subsequent geographical extension or changes in the scope of integration led not only to the EU expansion, but above all to a deepening cooperation within it. In this way, over years and decades, first the European Communities (EC) and then the European Union (EU) became a complex system of interdependencies, with intermingling interests of different entities with a varied character and scope of powers and influence. With time, it became evident that the institutional system formed - understood as the network of main EU institutions, today defined in Art. 13 of the Treaty on the European Union - is not able to effectively manage this complex process. For this reason, the need arose to create new entities that would support European institutions in carrying out their tasks by providing information, analyzing and proposing solutions for specific issues or drawing up executive instruments. The largest group among currently operating agencies are decentralized agencies. It is worth noting that there is no single legal definition of an agency in the EU institutional system. They are referred to as "regulatory", "traditional" or "satellite" agencies" (Analytical Fiche $N r^{\circ} 1,2010$ ). It is also difficult to

1 The European Commission President, José Manuel Barroso, stated that "The agencies are our [i.e., EC's - author's note] satellites - picking up signals on the ground, processing them and beaming them back and forth. Through their activities the agencies contribute to making «Europe» closer to the European citizens and hopefully easier to understand [...]" (The Community Plant..., 2006). 
find a direct Treaty basis for the creation of agencies of this type. It is recognized that they are appointed by the EU institutions on the basis of Art. 352 of the Treaty on the Functioning of the European Union (formerly Article 308 of the Treaty on European Community), which reads: "If action by the Union should prove necessary, within the framework of the policies defined in the Treaties, to attain one of the objectives set out in the Treaties, and the Treaties have not provided the necessary powers, the Council, acting unanimously on a proposal from the Commission and after obtaining the consent of the European Parliament, shall adopt the appropriate measures. Where the measures in question are adopted by the Council in accordance with a special legislative procedure, it shall also act unanimously on a proposal from the Commission and after obtaining the consent of the European Parliament" (Treaty on the Functioning..., OJ of the EU, C 202, 7 June 2016). Decentralized agencies have been created over the years in response to new challenges and needs of the EC/EU. This process has intensified since the $1990^{\mathrm{s}}$ as a result of creation of the internal market, but this multiplication was so chaotic and uncoordinated that significant differences in the status and functioning principles of different agencies emerged. In 2015, EU agencies employed a total of 6,554 staff, which constituted $13 \%$ of all EU employees (EU Agencies Working..., 2015). At the beginning of the 2000s, a need to create minimum standards common to all such entities became apparent. Activity initiated at that time led to the presentation by the European Commission in 2012 of the so-called Roadmap to regulate matters related to establishment, scope of activity and competences of the EU decentralized agencies (Roadmap..., 2012).

The topic of EU agencies is one of less frequently discussed issues in the field of European studies. Beyond the scientific community, knowledge about the agencies, their tasks and functions is negligible. So far only a few publications devoted to this subject have been published in the Polish language, including a monograph Agencje, komitety i inne jednostki organizacyjne w Unii Europejskiej [Agencies, Committees and Other Organizational Units in the European Union] edited by M. Witkowska \& K.A. Wojtaszczyk (Warsaw 2015), or another publication edited by A. Dumała - Agencje Unii Europejskie [Agencies of the European Union] (Warsaw 2002). In foreign language literature, particularly noteworthy is the book authored by M. Chamon, EU Agencies: Legal and Political Limits to the Transformation of the EU Administration (Oxford 2016) or the monograph edited by B. Rittberger \& A. Wonka, Agency Governance in the EU (Routledge 2012). A characteristic feature of English-language publications of recent years is the increasingly frequent use of the term agencification. This concept is used not only 
in the context of EU agencies, but has a wider application and refers to a quite common phenomenon of delegation of competences and regulatory powers by state institutions to specialized units formed for just such purpose (Christensen \& Lægreid, 2005). Similarities between the national and the EU level with regard to agencification do not only concern the process of establishing the agencies, but extend also to certain general principles in autonomization of such entities.

The paper presents the most important features of regulatory agencies and activities undertaken by the European Commission and other EU institutions to regulate and organize the principles of their functioning, as well as the contribution of the European Court of Justice in development of the doctrine regarding the position and role of such agencies in the Union's institutional system. The last section, serving also as a summary, is devoted to a deeper reflection on the phenomenon of agencification of the European Union.

\section{REGULATORY AGENCIES IN THE EU INSTITUTIONAL SYSTEM: ORIGIN, TYPOLOGY AND DEVELOPMENT}

Establishment and development of regulatory agencies was closely linked to the expanding range of responsibilities of the European Communities. The progress of European integration and creation of a single internal market has strengthened the supranational dimension of this integration ${ }^{2}$. In the institutional sense, the emanation of supranationality in the EU institutional system is the European Commission, which is primarily responsible for implementation of Community policies. Over time, the Commission was forced to look for external entities that would support its activities, at least as regards collection and analysis of information, as well as monitoring the progress in implementation by various entities of tasks assigned by the Communities. Discussing the issue of secondary delegation in transnational management, J. Ruszkowski stresses that "Formation of agencies in the EU is inevitable because it reflects the need to create Community regulators, and regulation is an immanent feature of transnational

2 The EU is an international organization with certain supranational features. The particular combination of these two models of integration makes the task of defining it highly challenging, hence usually the EU is described as a sui generis organization, where both Member States and supranational institutions have their specific competences. 
management that gradually overcomes national borders in order to gain a panEuropean dimension" (own transl. from Polish; Ruszkowski, 2010).

Going by the time of creation criterion, agencies can be divided into four generations. The first regulatory agencies were established in 1975. The first one was the European Center for the Development of Vocational Training with headquarters in West Berlin ${ }^{3}$ (Regulation (EEC) No 337/75, 1975), responsible for exchanging information, best practices and experiences, as well as organizing courses and trainings. The second agency was the European Foundation for the Improvement of Living and Working Conditions (Regulation (EEC) No 1365/75, 1975) based in Ireland ${ }^{4}$, whose main objective was to "spread knowledge" on the development and improvement of living conditions, as well as educational and training activities. The scope of responsibilities of these first agencies was not impressive, but they were a step in the direction of professionalization - not yet agencification at that time - of the decision-making process. Both agencies assisted the Commission by providing expert knowledge, and at the same time serving as a link between the national level - that of states where all main problems were identified - and the transnational one - i.e., that of the Commission, where subsequently a common approach was established.

The second generation agencies were created in the first half of the 1990s. The scope of their activities and competences was broader than those of the first generation. Of key importance to the development of EU agencies was the Decision Taken by Common Agreement Between the Representatives of the Governments of the Member States, Meeting at Head of State and Government Level, on the Location of the Seats of Certain Bodies and Departments of the European Communities and of Europol of 29 October 1993 (OJ of the EU, C 323, 30 November 1993). It identifies the headquarters of seven agencies, some of them already in existence since the beginning of the $1990 \mathrm{~s}^{5}$, but also some

\footnotetext{
3 In 1995, the Agency headquarters were transferred to Thessaloniki.

4 In the Regulation no specific city was indicated. Later on, the Irish government decided to locate the Agency in Dublin.

5 European Environment Agency (Council Regulation (EEC) No 1210/90 of 7 May 1990), head office in Copenhagen; European Training Foundation (Council Regulation (EEC) No 1360/90 of 7 May 1990), based in Turin; Office for Veterinary and Plant-Health Inspection and Control (Commission Decision of 18 December 1991), headquartered in Ireland; European Monitoring Centre for Drugs and Drug Addiction (Council Regulation (EEC) No 302/93 of 8 February 1993), based in Lisbon; European Agency for Evaluation of Medicinal Products (Council Regulation (EEC) No 2309/93 of 22 July 1993), with headquarters in London.
} 
whose emergence was only anticipated at that point ${ }^{6}$. The creation of a number of new agencies was a response to new challenges faced by the Union due to progressing liberalization of the flow of goods, services, capital, and people. In addition, transnational problems (such as organized crime) or those of a general nature, but affecting all Member States (such as pollution of the natural environment) have begun to emerge. Moreover, facing the prospect of the next Union enlargement with new Member States and the growing criticism of excessive centralization of the decision-making process at EU level, the choice to locate the headquarters of subsequent agencies in different countries seemed logical, though not entirely pragmatic. The agencies, whose main task is to support various aspects of work of different institutions but primarily the Commission, are geographically dispersed, which may cause disruptions in the communication process. An additional threat caused by such location of agencies in different countries is the possibility of their excessive autonomization "away" from the Commission, which should oversee them. However, legal and institutional solutions applied limit this latter possibility.

Establishment of subsequent agencies was related to consolidation of the internal market and another enlargement. This group includes agencies that were established in the period from late $1990^{\text {s }}$ to 2005 . The timeframe is set, on the one hand, by the aforementioned decision of 29 October 1993, which listed the specific (second generation) agencies and, on the other hand, the Draft Interinstitutional Agreement Presented by the Commission on the Operating Framework for the European Regulatory Agencies (COM (2005) 59 final), the purpose of which was to tidy up the rules for their establishment, operation and control. And although the agreement was not finally reached (Commission Seeks..., 2008), the draft itself became the foundation on the basis of which the later - fourth - generation of agencies were created. It also gave rise to deeper reflection and analysis, and a general evaluation of the current model of the agencies' operating framework.

6 Agency for Safety and Health at Work, based out of Spain; Office for Harmonization in the Internal Market, with headquarters in Spain. In addition, the Decision specified the headquarters of the European Monetary Institute, which was later transformed into the European Central Bank (Frankfurt am Main) and Europol, which at that time did not have the status of an EU agency (The Hague). 


\section{THE "NEW APPROACH"}

After the failure of the draft interinstitutional agreement of 2005, the Commission returned to the idea of regulating the functioning of agencies three years later. In 2008, a Communication from the Commission to the Parliament and the Council entitled European Agencies - The Way Forward (COM (2008) 135 final) was presented. José Manuel Barroso, then chairman of the Commission, said on this occasion: "The time has come to re-launch a debate on the role of agencies and the service they provide to the EU. European agencies have proved their worth - but the outstanding governance issues need to be addressed by our three institutions together. With a consistent political approach to agencies we can promote the transparency and effectiveness of an important part of EU's architecture" (Commission Seeks..., 2008). In the introduction to the Communication, one can read that establishment of the agencies one by one "has not been accompanied by an overall vision of the place of agencies in the Union" (COM (2008) 135 final), what has made their work difficult and less effective. The Commission stressed that the purpose of the new regulations in relation to the agencies is not to unify their manner of functioning, because it would be impossible and in fact not recommended due to their diverse nature and tasks. Instead, as the Commission states, it was necessary to strive for a balance between the agencies' specific characteristics and sufficient standardization of the rules for their functioning in the context of the entire institutional system of the Union. The document indicated several areas that should be regulated in the future. The first of these was the need to define certain categories of agencies in terms of their tasks - while it would not be possible to implement a single model for what an agency should do, it was decided to group agencies due to their main functions. In this way, four basic categories of agencies have been distinguished: agencies providing direct assistance to the Commission and other entities in the form of technical or scientific advice and expert services; agencies in charge of operational activities and finally those responsible for gathering, analyzing and forwarding information and data for other entities (COM (2008) 135). An important agenda item in the Communication were issues related to greater oversight over the agencies' work and their greater accountability, including financial and in terms of resource management, which can also be linked to the recommendation that agencies should focus on their core business. The next point concerned regulating agency relations with the EU institutions, including the Council and the Parliament. A reference was also made to better planning 
and impact assessment before a new agency is formally established and the development of standards and criteria for disbanding an agency. Finally, the need to strengthen the agencies' communication strategy was emphasized to improve public awareness and understanding of their role and activities among the EU citizens (COM (2008) 135).

In this way began a new debate on the role and tasks of EU agencies. In March 2009, an interinstitutional working group was formed, composed of representatives of the Commission, the Council and the Parliament (Kohtamäki, 2016). As a result of work of this group, a document entitled Joint Statement of the European Parliament, the Council of the EU and the European Commission on Decentralized Agencies was drawn up and later adopted on 19 July 2012. It contained a passage stating that "The establishment of agencies was done on a case by case basis and has not been accompanied by an overall vision of their role and place in the Union" (Joint Statement..., 2012). The Statement was intended for three main target groups that, in a joint effort, could contribute to improved regulation of the status and role of agencies. The first category are the Union institutions responsible for creation of agencies - namely, the Commission, issuing a request for an agency to be established, and the Council and Parliament, which formally, in a regulation, set up the said agency. The second group consists of the agencies themselves, upon which the EU institutions are calling to improve their performance and streamline their activities. Finally, the third category are the Member States whose task is to create conditions for agencies to operate as efficiently as possible. The annex to the Joint Statement includes specific recommendations, the implementation of which was intended to bring benefits to all stakeholders - primarily of course the agencies, but also those for whom the bulk of agencies' work is performed, i.e., the EU institutions and Member States. A total of 66 recommendations divided into five groups were formulated. The first group is The Role and Position of Agencies in the EU's Institutional Landscape. One of key goals in this grouping of recommendations is the unification of terminology. All agencies should use the term "European Union Agency for..." in their name - the previous practice in this respect was very diverse, and the official names of agencies included terms such as office, bureau, foundation, which could lead to misunderstandings and incorrect identification of these entities. Other recommendations laid down in this section concerned establishment, possibility of disbanding an agency or merging two agencies and rules on determining an agency seat and role of the host country. The second grouping was entitled: Structure and Governance of Agencies. This heading cov- 
ered the main governing bodies of agencies - Management Board, Director, and other internal bodies that may be appointed depending on the specific nature of a given agency. The third section focused on: Operation of Agencies. Here some rationalization suggestions were made to improve the agencies' efficiency, including taking into consideration the option to merge smaller agencies to make better use of available resources. Another important point made was the emphasis placed on the need to exchange information and formulate strategies for international cooperation in the case of agencies whose mandate foresees such activities. The fourth chapter was entitled: Programming of Activities and Resources. Agencies should prepare annual work plans that would be subject to review by the Commission according to a standardized template. Multiannual action plans would additionally be presented to the Parliament. Also, management of human resources (personnel policy) and financial resources should be as uniform and transparent as possible. The fifth category of recommendation was: Accountability, Controls and Transparency and Relations with Stakeholders. It was noted that the reporting of agencies must be harmonized (with possible certain exception due to specific characteristics of a given agency) and streamlined. Agencies were to be subject to internal and external audits. An important provision was the introduction of agency evaluations to be carried out every five years. In addition, every second evaluation was to be linked to the sunset/ review clause for the agency in question, a solution which should lead to a more rationalized agency system where, in the absence of expected results or in light of lack of further justification of an agency's operation, a decision could be made about discontinuation of its mandate. Another item in the section pointed to the need for better communication between agencies and their stakeholders and external environment, for example, through better-managed websites in a possibly wide range of official EU languages. Another novum in the approach to agency governance was the introduction of an alert/warning system. It was to consist in the Commission being able to block a decision of the Management Board of an agency if it considered such a decision contrary to European Union law, Union policy objectives or to be outside the mandate of the agency. If the Management Board was to ignore the Commission's objections, the Commission would inform the Parliament and the Council thereof so that ultimately all three institutions can react. The last point under this heading concerned enhancing the competences of the European Anti-Fraud Office (L'Office européen de lutte antifraude, OLAF) vis-a-vis agencies to better prevent corruption and other illegal practices. 
It should be noted that the Joint Statement was not binding, but was an expression of goodwill and openness of the three institutions to improve the regulation of the EU agencies operating framework.

The next step of the Commission was to develop a Roadmap for implementing a common approach to decentralized agencies (Roadmap..., 2012). The document was adopted in December 2012, and contained a detailed plan of actions that should be undertaken to implement the principles laid out in the Joint Statement. The Roadmap identified the instruments by which the Commission wanted to achieve the objectives of the common approach. Individual action points, totaling 90, with assignment of roles to individual entities responsible for their implementation (the Commission, the Parliament, the Council, the European Council - a single item, Member States and agencies) and the planned timetable were shown in a table.

In the first place, the Commission planned to propose changes to legal instruments establishing the agencies in order to adapt them to the requirements set out in the Joint Statement. Next, other regulations, including staff regulations, as well as the framework financial regulation would be subject to revisions and changes. In addition, the Commission wanted to strengthen the position and role of its representatives in the agencies' Management Boards so that an alert/ warning system could be deployed.

\section{ASSESSMENT OF THE "NEW APPROACH"}

The Commission, which is responsible for implementing the common approach, has so far prepared two reports with analogous structure. The Commission presents in them its progress in implementing the Roadmap, amending the agencies' founding acts and enhancing the role of the Commission's representatives in agencies' Management Boards. The first report was published in December 2013 and contained an initial assessment of the progress in implementing actions specified in the Roadmap (Commission Progress..., 2013). Due to the short time between formulating the Roadmap and the first report, the latter was relatively laconic and addressed only some of the items. The Commission has developed rules that should be taken into account in setting up new agencies, as well as guidelines for headquarter agreements for the agencies. The Commission also presented proposals to amend the founding acts of seven agencies, adapting them to the requirements of the Common Approach. One of the most impor- 
tant suggestions made by the Commission was the idea of combining CEPOL with Europol. Based on a detailed analysis of the tasks of both agencies, it was concluded that such a solution would contribute to a more rational management of financial and human resources. However, the proposal was rejected by the Council and Parliament, and the status quo of both agencies was maintained.

The second report was presented by the Commission on 24 April 2015 (COM (2015) 179 final). The Commission reported that a template for the agencies' annual consolidated activity report has been developed. Agencies will be required to submit this document for the first time for the financial year 2017. With regard to rationalizing the use of financial and human resources by the agencies, the Commission has taken a number of actions, including on provision of services by the agencies, support in the field of public procurement, support in certification of annual accounts of the agencies. One of the most important points included in the report is the announcement of the planned reduction in the number of staff'. The Commission also issued guidelines on performance indicators for agencies, a tool that would allow for a more objective and reliable assessment of executive directors and discharge of the agencies duties. In the section on changes in agencies' founding acts, the Commission pointed to lack of political commitment to ensure implementation of the common approach, in particular regarding the role and composition of the agencies' management structures. This demonstrates an inconsistency in the activities of EU institutions aimed at reforming the system of decentralized agencies. Nevertheless, the Commission underlines its determination to continue working on full implementation of principles set out in the Common Approach and detailed in the Roadmap (COM (2015) 179 final).

\section{ROLE OF THE EUROPEAN COURT OF JUSTICE IN SHAPING THE POSITION OF AGENCIES IN THE EU INSTITUTIONAL SYSTEM}

When discussing the functioning of EU agencies, highly worth noting is the Meroni doctrine. Although almost 60 years have passed since the judgment in the case of Meroni v. High Authority of the ECSC, the guidelines on delegation of

7 It is a general commitment applicable to all EU institutions, bodies and agencies. In the multiannual financial framework for 2014-2020, these entities committed themselves to reducing the number of employees by $5 \%$ by 2018 . 
authority formulated at that time have determined the framework and boundaries of delegation of powers by EU entities that are not based directly on Treaty provisions. The Meroni case concerned competences of the so-called Brussels agencies, entities completely external to the Communities, but the guidelines formulated by the European Court of Justice (ECJ) applied to delegation of powers to any entities, without restrictions in this regard. From the Meroni doctrine, the following restrictions apply to the delegating entities: first, an entity cannot delegate more rights than it has itself; second, only executive competences can be delegated; third, discretionary powers cannot be delegated; fourth, delegated powers must have a clear legal basis and must be subject to judicial review; fifth, the delegating institution must have the right to control the entity to which it delegated the exercise of its powers (Case 9-56, 1958). The Meroni case is often cited in the literature and commonly associated with the limitations imposed on EU institutions as concerns delegation of powers. However, this is not the only ECJ ruling that should be taken into consideration when discussing matters related to agencies and their powers.

In 1981, the Court of Justice issued a judgment in the Romano case (Case $98 / 80,1981$ ). The Court considered the reference from a national court for a preliminary ruling on the interpretation and validity of Decision No 101 of the Administrative Commission of the European Communities on Social Security for Migrant Workers established under a 1972 Regulation. In its judgment, the ECJ stated that the Council could not authorize the Administrative Commission to adopt legally binding acts. As M. Chamon points out, the Romano judgment is of greater importance for the principles of functioning of EU agencies than the Meroni ruling (Chamon, 2011). Firstly, the Meroni ruling was based on the provisions of the Treaty on the European Coal and Steel Community (ECSC), while the Romano judgment was based on the European Economic Community Treaty (EEC). Secondly, the Meroni ruling concerned the delegation of powers by the High Authority, whereas the Romano case concerned powers delegated by the Council. And thirdly and most importantly, the subject of the Meroni ruling were private agencies (in Brussels) established and operating under private (Belgian) law, while the Romano ruling concerned an entity established on the basis of secondary law (Chamon, 2011). For these reasons, when analyzing the functioning of agencies in the Union's institutional system, both of the above judgments should be taken into account. The first one formulates general guidelines related to the delegation of powers, and the second in turn better reflects the context in which today's regulatory agencies operate. 
The matter of agencies and their competences became the subject of proceedings before the Court again in 2014, when a ruling was passed in the case United Kingdom of Great Britain and Northern Ireland v European Parliament and Council of the European Union concerning the powers conferred under the 2012 Regulation (Regulation of the European Parliament and of the Council (EU) No 236/2012) onto the European Securities and Markets Authority established in 2011. In its claim, the United Kingdom invoked both Meroni and Romano, arguing that the EU legislature violated the limits imposed on the scope of delegation of powers and that the agency (Authority) in question was granted the competence to adopt generally applicable instruments of a normative character. The allegations raised by the United Kingdom were rejected entirely by the Court. Nevertheless, it is worth referring to the opinion of Advocate General Niilo Jääskinen in this case, who pointed to the new legal and treaty context of agencies' functioning after the entry into force of the Treaty of Lisbon. He noted that "[...] the evolution in the EU constitutional law that occurred under the Lisbon Treaty has indeed accommodated the pivotal concerns with which the Court had to deal in Meroni and Romano; namely, the absence of treaty based criteria for the conferral and delegation of powers so as to ensure respect for institutional balance, and the vacuum in terms of judicial review of legally binding acts of agencies" (Opinion of Mr Advocate General..., Case C-270/12).

\section{EU AGENCIFICATION. CONCLUSIONS}

The increase in the number and significance of decentralized agencies has started a reflection on their phenomenon from an entirely new perspective. The concept of "agencification" is not a new term and has not been created in connection with EU agencies; it has been transplanted from handbooks of management at the national level. It is worth recalling that agencies are not only known as relevant players at the EU level, but above all, they are active and widely used at the national level. State administrations create agencies with the same purpose as the EU does - for the agencies to offer administrative, regulatory support or expert knowledge and skills to various state bodies. Decentralization of national agencies also has an economic dimension - thanks to such a solution, it is possible for the agencies' potential and resources to be used by various groups of entities. The same applies to their operation at the EU level. Therefore, it is not surprising that theories and research on agencies are transplanted from 
the national to the EU level. There are several perspectives in the study of EU agencies: intergovernmental, transnational, and supranational. These approaches not only do not contradict each other, but to the contrary, agencification of the European Union is a combination of these three perspectives with a different weight assigned to each depending on the studied period (Egeberg \& Trondal, 2016). The answer as to which of the perspectives is dominant is basically the answer not only to the question on the position of agencies in the EU institutional system, but above all, to the question of their role in the complicated system of dependencies between interests of individual Member States and those of the supranational institutions of the EU (first of all, the Commission). The intergovernmental approach assumes that agencies are largely dependent on Member State governments, inter alia, by being subject to control by state representatives within the agency. In addition, this perspective points out that agencies serve not the Commission as such, but rather the governments of Member States, ensuring implementation or monitoring implementation of policies agreed at the level of intergovernmental institutions (the Council; Egeberg \& Trondal, 2016). The supranational perspective gives a completely different position to agencies in the institutional system - for proponents of this approach, agencies are an integral part of the administrative apparatus of the Union, and their control by member states and the Commission is intended to ensure centralization of their regulatory functions, so that the decisions taken by them are universally applicable throughout the Union (Egeberg \& Trondal, 2016). The most interesting perspective, however, seems to be the transnational approach. It places agencies in-between the national and supranational levels. Supporters of this approach emphasize that agencies enjoy a vast degree of autonomy and remain free from political influence as technocratic structures.

The phenomenon of EU agencification consists in not only an increase in the number of agencies, but above all, in the increase of their importance. In functional terms, agencies fulfill a variety of roles, including delivery of expert analyses of issues and proposing solutions to problems that are often of a transnational nature. Agencies are, and in any case should be, free from political pressure, although, as is also pointed out, they can sometimes assume the responsibility for unpopular decisions taken and thus help their "principals", i.e., the EU institutions. One should note that agencies operate in strictly defined areas or topics and have detailed knowledge about them. This in turn leads to asymmetry in access to information, which is undoubtedly one of the agencies' greatest assets and an argument difficult to deny, even for their opponents (Chamon, 2016). 
In organizational terms, position of the agencies is not clear. In a simple framework divided into the national (member states and intergovernmental institutions - the Council of the European Union and the European Council) and the supranational level (mainly the European Commission) in the EU, it is difficult to decide where agencies should be positioned. A solution to this problem may be the application of the multi-level governance model, MLG (Trnski, 2005), where apart from state actors and supranational institutions also other entities influencing the process of European integration and shaping European policies are introduced. Application of the multi-level management model allows to partially describe the place of decentralized agencies in the European Union system. Their position is thus in-between the level of member states and the level of supranational institutions. Decentralized agencies are defined in organizational terms as public law entities with legal personality and are guaranteed administrative and financial autonomy. In addition, they are created by the Council and the European Parliament on the basis of secondary law instruments (regulations; Vos, 2013). On the other hand, it should be remembered that the political impulse for creation of an agency comes from the Commission and the agencies most often support and provide services to this institution. However, as it is a process that does not have a clear basis in the Treaty provisions, it is sometimes said that agencies operate in the so-called gray zone between what can be called the EU administration (a bureaucratic system) and the purely political sphere in which decisions are made (Vos, 2000).

Agencification of the European Union was not a planned operation of any of its institutions or other actors (Member States). It can be treated as an evolutionary process that was initiated in the $1990^{\mathrm{s}}$ and continues to this day, with attempts being made currently to structure it and give it a common legal and organizational framework. In summary, the term "agencification" as it is used in the field of European studies has not yet been fully defined, which should not come as a surprise as it is a phenomenon that is still evolving. Only some characteristic features of this phenomenon can be identified, which undoubtedly include, in static terms, an increase in the number of agencies, but above all, in dynamic terms, an increase in their importance in the processes shaping European policies, associated with a desire to relieve the Commission of purely technical and expert tasks. Financial issues related to establishment of agencies are also important. The original goal in creating agencies was to rationalize costs and reduce expenditures by creating highly specialized units within the EU system, so it could become independent from the need to outsource and pay high fees 
for analyses made by external entities. However, over time it turned out that the agencies themselves, due to expansion of their administrative structures, started to generate high operational costs, which is currently the object of a reform of the decentralized agencies system undertaken by the Commission. It is also worth noting that EU decentralized agencies often cooperate with national agencies, not only that of member states, but also of third countries, creating networks of agencies, which may be another important element in the attempt to define the phenomenon of the EU agencification. A good example here is the European Environment Agency, which works with member states' agencies and a number of agencies from countries outside the Union (33 countries are members of the Agency and another six have the status of cooperating countries), creating the Eionet network (Who We Are, 2018). From a theoretical perspective, one can define it as a hub and spokes structure, where the EU agency is the center (hub), and national agencies (or other entities cooperating with it) are connected with it, although they retain their independence and autonomy.

Therefore, the process of agencification should not be perceived as a threat to the institutional framework of the Union or to the division of competences specified in the Treaty, but rather as an attempt to professionalize the process of creating European policies in an increasingly complex system of economic interdependencies and social issues. Agencies have already become a fixed element in the EU institutional system and it is difficult to imagine the Union's functioning without them - which, however, does not mean that one should not debate the principles of their operation.

\section{REFERENCES:}

Analytical Fiche $\mathrm{Nr}^{\circ} 1$ (2010). Definition and Classification of "European Regulatory Agency”. Portal Unia Europejska. Retrieved from: https://europa.eu/european-union/ sites/europaeu/files/docs/body/fiche_1_sent_to_ep_cons_2010-12-15_en.pdf.

Case 9-56 (1958). Judgment of the Court of 13 June 1958. Meroni \& Co., Industrie Metallurgiche, SpA v High Authority of the European Coal and Steel Community.

Case 98/80 (1981). Judgment of the Court (First Chamber) of 14 May 1981. Giuseppe Romano $v$ Institut national d'assurance maladie-invalidité. Reference for a Preliminary Ruling: Tribunal du travail de Bruxelles - Belgium. Social Security - Applicable Exchange Rate.

Chamon, M. (2011). EU Agencies Between Meroni and Romano or the Devil and the Deep Blue Sea. Common Market Law Review, 48(4), 1055-1075. 
Chamon, M. (2016). EU Agencies: Legal and Political Limits to the Transformation of the EU Administration. Oxford: Oxford Studies for European Law.

Christensen, T., \& Lægreid, P. (2005). Regulatory Reforms and Agencification. Stein Rokkan Centre for Social Studies, Working Paper, 6. Retrieved from: http://uni.no/ media/manual_upload/114_N06-05_Christensten-Laegreid.pdf.

Commission Decision of 10 February 1997 Concerning the Information to be Entered in the Computerized File of Consignments of Animals or Animal Products from Third Countries which Are Re-dispatched (Text with EEA Relevance) (1997). OJ of the EU, L 59, 28 February 1997.

Commission Progress Report on the Implementation of the Common Approach (2013). Retrieved from: https://europa.eu/european-union/sites/europaeu/files/docs/ body/2013-12-10_progress_report_on_the_implementation_of_the_common_ approach_en.pdf.

Commission Seeks Common Approach on the Future Governance of European Agencies (2008). Retrieved from: http://europa.eu/rapid/press-release_IP-08-419_pl.htm.

Communication from the Commission to the Parliament and the Council Entitled "European Agencies - The Way Forward" (2008). COM 135 final.

Council Regulation (EEC) No 1210/90 of 7 May 1990 on the Establishment of the European Environment Agency and the European Environment Information and Observation Network (1990). OJ of the EU, L 120, 11 May 1990.

Council Regulation (EEC) No 1360/90 of 7 May 1990 Establishing a European Training Foundation (1990). OJ of the EU, L 131, 7 May 1990.

Council Regulation (EEC) No 2309/93 of 22 July 1993 Laying Down Community Procedures for the Authorization and Supervision of Medicinal Products for Human and Veterinary Use and Establishing a European Agency for the Evaluation of Medicinal Products (1993). OJ of the EU, L 214, 24 August 1993.

Council Regulation (EEC) No 302/93 of 8 February 1993 on the Establishment of a European Monitoring Centre for Drugs and Drug Addiction (1993). OJ of the EU, L 36, 12 February 1993.

Decision Taken by Common Agreement Between the Representatives of the Governments of the Member States, Meeting at Head of State and Government Level, on the Location of the Seats of Certain Bodies and Departments of the European Communities and of Europol of 29 October 1993 (1993). OJ of the EU, C 323, 30 November 1993.

Draft Interinstitutional Agreement Presented by the Commission on the Operating Framework for the European Regulatory Agencies (2005). COM 59 final.

Dumała, A. (ed.) (2002). Agencje Unii Europejskiej. Warszawa: Urząd Komitetu Integracji Europejskiej.

Egeberg, M., \& Trondal, J. (2016). Agencification of the European Union Administration Connecting the Dots. ARENA Working Paper, 3, 1-24. Retrieved from: https:// www.sv.uio.no/arena/english/research/publications/arena-working-papers/2016/ wp-3-16.pdf. 
EU Agencies Working for You (2015). European Union Agency for Fundamental Rights. Retrieved from: http://www.cleansky.eu/sites/default/files/inline-files/EU\%20Agencies\%20brochure\%20\%281\%29.pdf.

Joint Statement of the European Parliament, the Council of the EU and the European Commission on Decentralized Agencies, Adopted on 19 July 2012 (2012). Retrieved from: https://europa.eu/european-union/sites/europaeu/files/docs/body/joint_ statement_and_common_approach_2012_pl.pdf.

Kohtamäki, N. (2016). Autonomia instytucjonalna urzędów regulacyjnych Unii Europejskiej: przykład Europejskiej Agencji Bezpieczeństwa Lotniczego. Internetowy Kwartalnik Antymonopolowy i Regulacyjny, 5(2), 56-69. DOI: 10.7172/2299-5749. IKAR.2.5.5. Retrieved from: https://ikar.wz.uw.edu.pl/numery/33/pdf/00.pdf.

Opinion of Mr Advocate General Jääskinen Delivered on 12 September 2013. United Kingdom of Great Britain and Northern Ireland $v$ European Parliament and Council of the European Union. Regulation (EU) No 236/2012 - Short Selling and Certain Aspects of Credit Default Swaps - Article 28 - Validity - Legal Basis - Powers of Intervention Conferred on the European Securities and Markets Authority in Exceptional Circumstances. Case C-270/12.

Progress Report on the Implementation of the Common Approach on EU Decentralised Agencies. Report from the Commission (2015). COM 179 final.

Regulation (EEC) No 1365/75 of the Council of 26 May 1975 on the Creation of a European Foundation for the Improvement of Living and Working Conditions (1975). OJ of the EU, L 139, 30 May 1975.

Regulation (EEC) No 337/75 of the Council of 10 February 1975 Establishing a European Centre for the Development of Vocational Training (1975). OJ of the EU, L 039, 13 February 1975.

Regulation (EU) No 236/2012 of the European Parliament and of the Council of 14 March 2012 on Short Selling and Certain Aspects of Credit Default Swaps Text with EEA Relevance (2012). OJ of the EU, L 86, 24 March 2012.

Rittberger, B., \& Wonka, A. (eds.) (2012). Agency Governance in the EU. Routledge: Abingdon.

Roadmap on the Follow-up to the Common Approach on EU Decentralised Agencies (2012). Retrieved from: https://europa.eu/european-union/sites/europaeu/files/ docs/body/2012-12-18_roadmap_on_the_follow_up_to_the_common_approach_ on_eu_decentralised_agencies_en.pdf.

Ruszkowski, J. (2010). Ponadnarodowość w systemie politycznym Unii Europejskiej. Warszawa: Oficyna a Wolters Kluwer business.

The Community Plant Variety Office Joins a New Campaign on EU Agencies (2006). Press

Release $6^{\text {th }}$ December 2006. Retrieved from: http://old.cpvo.europa.eu/documents/ News/documents/PR_joint_campaign_on_EU_Agencies.pdf.

Treaty on the Functioning of the European Union (2016). OJ of the EU, C 202, 7 June 2016. 
Trnski, M. (2005). Multi-Level Governance in the EU. In: I. Tarrosy, \& G. Rosskogler (eds.), Regional Co-Operation as Central European Perspective (pp. 23-32). Pecs: Europe Centre PBC.

Vos, E. (2000). Reforming the European Commission: What Role to Play for EU Agencies? Common Market Law Review, 37(5), 1113-1134. DOI: 10.1023/ A:1005671621413. Retrieved from: https://www.kluwerlawonline.com/abstract. php?area=Journals\&id $=276512$.

Vos, E. (2013). EU Agencies: Features, Framework and Future. Maastricht Faculty of Law Working Paper, 3, 1-40.

Who We Are (2018). The European Environment Agency. Retrieved from: https://www. eea.europa.eu/en/about-us/who/who-we-are\#parent-fieldname-title.

Witkowska, M., \& Wojtaszczyk, K.A. (eds.) (2015). Agencje, komitety $i$ inne jednostki organizacyjne w Unii Europejskiej. Warszawa: Oficyna Wydawnicza ASPRA-JR. 